\title{
THE ENGLISH SPEAKING ANXIETY OF PUBLIC HEALTH STUDENTS OF STIK BINA HUSADA PALEMBANG
}

\author{
By: \\ Agus Wahyudi \\ Nursing Science Study Program, STIK Bina Husada Palembang, South Sumatera \\ wahyudiagus.aw@gmail.com
}

\begin{abstract}
The learning process is an adaptation method dole out by people to grasp and master the science. During this learning period that the individual adjusts himself to the changes that occur quickly and surely. Speaking publically will cause anxiety as a result of each activity dole out by humans contains a tendency to develop anxiety. Horwitz (2001) expresses that one-third of the scholars who study foreign languages expertise a minimum of at a median level. The subjects were 13 students of the sixth semester who took English for Public Health in the academic year of 2020/2021. The frequency and the English speaking anxiety level became the purpose of this study to be found out. To collect the data English speaking anxiety questionnaire was used. The first questionnaire results showed that 2 students (15\%) answered very often, 4 students (30\%) often, 6 students (46\%) rarely, and 1 student (7\%) never felt anxious when speaking English. The second questionnaire showed that 2 students $(15 \%)$ in high category, 10 students $(76 \%)$ in medium, and 1 student (7\%) in low anxiety. In accordance to the students' answer, it is hoped that scholars understand that it is natural to form mistake in form.
\end{abstract}

Keywords: English, speaking, anxiety

\section{INTRODUCTION}

Speaking is an approach to impart where individuals can share information, data and thoughts. In speaking, students find it difficult to talk although they have a lot of pronunciation.

When speaking, students create information with syllables and express perceptions, feeling, and intentions so that the interlocutor understands what the speaker meant. For this reason, voice communication or spoken principle is considered. Further, Brown (2007) expresses some personality factors as well as self-esteem, disposition to speak, inspiration, and so 
on that affects students in learning speaking.

Speaking anxiety during foreign language can be caused by varied factors. First, students might feel anxious when they are expected to communicate with others. These reasons may be psychological factors (emotions, self-esteem, anxiety, attitudes, fear, and motivation), instructional factors (classroom steps application and faculty-student relations) and situational setting (such as speaking ahead of a whole class). Woodrow (2006) explains that foreign language anxiety is a drawback in language learning and has a negative result in speaking English for a few students.

Second, the scholars will feel speaking anxiety once their speaking ability is evaluated. One reason for this is perfectionism, as a result students sometimes make illogical things that make their performance less perfect. The last, students are sacred to be assessed by the others.

During the Covid-19 pandemic, English learning was carried out online. at STIK Bina Husada Palembang, the English learning can be implemented through zoom meetings, google meetings, edlinks and other online learning applications. The writer saw that there are still some students who are unwilling to answer the questions given in English, or keep silent when questions are asked.

However, the online learning can give negative effects. According to Cubukcu (2007), fear of negative evaluations is a common factor in language learning. Nevertheless, it is a natural sense, classmates or peers are still a contributing factor to students' speaking anxiety in their learning process. In a foreign language, fear can be caused by various factors. One of the 
factor is students' anxiety when they are expected to communicate with others.

Based on the elaboration above, it is interesting to investigate students' problem in speaking at Public Health Study Program STIK Bina Husada.

\section{The Components of Speaking Skill}

As indicated by Syakur (1989, p. 5), some aspects of speaking, namely grammar, vocabulary, pronunciation, and fluency make speaking is considered more difficult that the other skills.

\section{1) Grammar}

It is required for understudies to organize a right sentence in discussion. The utility of sentence structure is additionally to become familiar with the right method to pick up mastery in a language in oral and composed structure.
2) Vocabulary

It implies the suitable word usage which is utilized in correspondence. Without having an adequate jargon, one can't impart successfully or express their thoughts in both oral and composed structure. Having restricted vocabulary is likewise a boundary that blocks students from learning a language.

3) Pronunciation

It is the route for understudies' to deliver more clear language when they talk. It manages the phonological cycle that alludes to the segments of a syntax comprised of the components and rules that decide how sounds differ and design in a language.

4) Fluency

It can be characterized as the capacity to talk easily and precisely. Familiarity with talking is the point of numerous language students. Indications of familiarity incorporate a 
sensibly quick speed of talking and just few stops and "ums" or "ers".

\section{Contributing Factors to Speaking}

Anxiety

Horwitz, Horwitz, and Cope (1986) mention three primary language performance anxieties, such as "social evaluation", "test anxiety", and “communication apprehension". While Young (1991) identifies six aspects that influence the language anxiety, they are: personal and interpersonal, personal belief regarding language learning, instructor beliefs regarding language teaching, instructor-learner interaction, classroom procedure, and language test.

Tension can ascend from different sources. It in some cases comes from classroom exercises and strategies which identified with instructors directions and errands. For instance, Speaking exercises it shows up as often as possible as one of the tension inciting factor. Young (1991) finds that communicating in the unknown dialect as the most nervousness delivering experience. In speaking understudies are attempted to convey in their restricted capacities. They also are scared of being evaluated by the teacher and friends which find their weakness. Besides, a few cases understudies regularly chuckled at their friends who commit an error. It totally commits understudies dread of making error. There dread of causing moron of themselves out in the open so they to like to hush up instead of address practice their English dread of being giggled at by other is probably the best wellspring of uneasiness.

\section{METHODOLOGY}

In this research, the writer utilized descriptive technique to clarify the data gathered. The analysis isn't simply exclusively limited to the matter of 
amassing and gathering the information, anyway additionally incorporate the examination and translation of the significance of the information. This research was directed by on-line to the students of STIK Bina Husada Palembang, there was thirteen understudies met the standard. Those thirteen understudies comprise of one male and twelve female understudies.

To acquire this exploration information, the scientist dispersed two questionnaires, the underlying is the frequency of students' speaking anxiety, the appropriate response's decisions are begun from very often, often, rarely and never and the second is speaking anxiety questionnaire adjusted from Horwitz, Horwitz, and Cope (1986). To answer these surveys, understudies are approached to fill their feeling by utilizing a Likert scale.

\section{RESULT AND DISCUSSION}

The following table shows the result of students' English speaking anxiety. The research was conducted on Wednesday, November 2020.

Table 1

English Speaking Anxiety Frequency

\begin{tabular}{ccc}
\hline Frequency & Sum & Percentage \\
\hline Very often & 2 & $15 \%$ \\
Often & 4 & $30 \%$ \\
Rarely & 6 & $46 \%$ \\
Never & 1 & $7 \%$ \\
\hline
\end{tabular}

There was 1 student or $7 \%$ who stated never feel anxious when speaking English, 6 students (46\%) in rarely category, 4 students (30\%) were in often category and 2 students $(15 \%)$ in very often category when they spoke English.

The subsequent survey was about understudies' English speaking anxiety, the understudies answers were sorted into high medium, and low. The outcome is brought into the accompanying table. 
Table 2

English Speaking Anxiety Level

\begin{tabular}{ccc}
\hline Level & Frequency & Percentage \\
\hline High & 2 & $15 \%$ \\
Medium & 10 & $76 \%$ \\
Low & 1 & $7 \%$ \\
\hline
\end{tabular}

There were 2 students (15\%) in high level, $10(76 \%)$ students were in medium level and $1(7 \%)$ student was in low level. the result of this research showed that majority of the public health science students, STIK Bina Husada Palembang in academic year 2020/2021 in medium level. Anxiety may happen as an impact of one's inability to build up the particular aptitudes important for settling on profession choices. Then again it might be seen as a causative factor in profession uncertainty.

Language anxiety may bring about sure and negative effect on understudy's exhibition. A few students enjoy language uneasiness, however some will in general maintain a strategic distance from tension inside the classroom. A negative tension appeared inside the consequence of an examination led by MacIntyre and Gardner (1989) utilizing centered paper strategy to the understudies. It demonstrated that restless understudies who composed an article indicated less trust in assembling words contrasted with loosened up understudies. This investigation proposes that tension identifies with understudy's selfassurance in language aptitudes application, so the understudy tries not to any learn task that makes them disappoint.

\section{CONCLUSION}

In light of the consequences of investigation, the basic understudy felt rarely feel anxious while communicating in English, that is six understudies, anyway four understudies often feel on anxious and two understudies said often. It was likewise 
upheld constantly questionnaire results; the English anxiety survey additionally found that most of understudies are in moderate level, two understudies at high level and one understudy at low level. There are several efforts to prevent and reduce student anxiety, including:

1) Making a fun learning atmosphere

2) Throughout learning activities the teacher ought to be able to develop a sense of humor for himself and his students

3) Doing alternate activities, such as games.

4) Carrying out learning activities outside the classroom, so within the learning process students do not always have to be confined in the classroom.

5) Providing material and tutorial assignments with a moderate level of difficulty, which means it is neither too easy nor too difficult.
Through the above efforts, it is hoped that students will avoid various forms of anxiety and they will grow and develop into physically and psychologically healthy individuals.

\section{REFERENCES}

Brown, H. D. (2007). Principles of language learning and teaching. New York: Longman

Cubukcu F. (2007). Foreign language anxiety. Iranian Journal of Language Studies, 1(2).

Horwitz, E.K. (2001). Language anxiety and achievement. Annual Review of Applied Linguistics, 21, 112-126.

Horwitz, E. K., Horwitz, M. B., \& Cope, J. (1986). Foreign language classroom anxiety. The Modern Language Journal, 70(2), 125-132.

MacIntyre, P.D \& Gardner, R.C. (1989). Anxiety and secondlanguage learning: Toward a theoretical clarification. Language Learning, 39(2), 251-275

Woodrow, L. (2006). Anxiety and speaking English as a second language. RELC Journal, 37, 308328.

Syakur. (1989). Language testing and evaluation. Surakarta: UNS Press. 
Agus Wahyudi

Young, D. J. (Ed). (1991). Affect in foreign language and second language learning: A practical guide to creating a low-anxiety classroom atmosphere. Boston: McGraw-Hill Colleg 